\title{
Group Guidance to Increase Peer Counselor and Understanding of Bullying
}

\author{
Yuliana $^{1^{*}}$, Neviyarni ${ }^{2}$, Marlina $^{3}$ \\ ${ }^{123}$ Padang State University \\ *Corresponding author, e-mail: yulie.friends@yahoo.com
}

\begin{abstract}
Peer counsellors have a low understanding of bullying and assume that bullying is common. The purpose of this research is to determine the effectiveness group counselling services to increase peer counsellor understanding of bullying. Methods Quasi Experiment study approach through the design of The Non-Equivalent Control Group. Data were collected using a peer counsellor understanding scale about bullying ( 53 valid items $=0.949$ ). The study sample consisted of 10 peer counsellors as a control group and 10 peer counsellors as an experimental group who had a low and moderate understanding. Data were analyzed using the Wilcoxon Signed-Rank test and Kolmogorov-Smirnov two independent sample. The findings of this study showed that group counselling services are effective in improving the understanding of peer counsellor about bullying.
\end{abstract}

Keywords: Guidance Services Group, peer Counselor, bullying.

How to Cite: Yuliana, Y., Neviyarni, N., Marlina, M. (2020). Group Guidance to Increase Peer Counselor an Understanding of Bullying. International Journal of Applied Counseling and Social Sciences. 2 (1): 25-30. DOI: 10.24036/005345ijaccs

\section{Introduction}

Schools face social problems because of a failure to understand the social environment and the difficulty in interpreting the problems that occur in the school environment (Marlina \& Kusumastuti, 2019). Social problems that often occur in schools is a matter of relationships with peers. In the association teens, almost all the time spent teens are interacting with their social environment, either with parents, siblings, teachers, friends, and so on (Arofah \& Suroso, 2015). Therefore, the figure of the teacher and the parent, the environment and good peer into the determination of the student's behaviour. Santrock (2010) stated the problem of the relationship is the same age bullying (a type of intrusive action in the form of terror peer harassment, bullying, intimidation, violence, insults, and the like). behaviour bullying become an important issue that must be prevented and overcome if the amount is increased, Indonesia included in the four countries with the highest in the world bullying case 
(Wardhana, 2015). Arofah \& Suroso (2015) states that bullying is a big chance to be imitated because most students tend to do after their bullying had been hurt by the stronger, for example by a parent, older sibling, seniors, or peers are more dominant. Swearer \& Hyme (2015) reveal the individual doing the bullying influenced by peers, family, teachers, and the environment in doing the bullying. Bullying by Nickerson (2019) can have an impact on the offender, the victim and the witness.

Caring teachers influence on students. The attitude of the teacher full of warmth and acceptance desired by every student (Marlina, Hendrawati, \& Kusumastuti, 2019). Trisnani \& Wardhani (2016) explain that bullying behaviour can be prevented by the presence of caring and cooperation among the school community. To overcome the problem of bullying need for prevention, one of the ways that can be done to improve the understanding of bullying by the entire school community and peer counsellor. The students who have an understanding of the dangers of bullying will have a better chance to avoid bullying than students who do not have an understanding of the dangers of bullying (Prahardika, 2014). There is a prohibition against bullying Al-Quran surah (Al-Hujurat verse: 11) was saying do not mutually deprecating, mocking and making fun of someone with a degree that is not his favourite, be it in the form of individuals and groups.

Olweus (Santrock, 2010) in a longitudinal study of men who have experienced bullying victim when they were in junior high school at age 20 showed they were more likely to feel depressed and low self-esteem than those who have never been a victim. The importance of peers is also associated with several aspects such as the development of emotional security, positive self-image, social competence, fulfilling the need for closeness, adopt prosocial behavior and satisfaction (Sandri, 2015). Saman, Thalib, \& Bakhtiar (2012) ) stated that if there are problems in themselves more teenagers communicated to peers rather than a counsellor at the school either directly or through the counseling guidance service. Revealed the role of peers in the lives of students is very important to solve the problems they face. Sarmin (2017) Students are more comfortable telling their peers than coming to the counselling and counselling room to consult the problems they face.

Priyatna (2010) said that the most effective medicine for relational problems is the right solution, relational. Peer counsellors can help solve problems in friendships. Sullivan (2001) explains that peer counsellors can overcome bullying problems. One effort schools can do that to help overcome bullying problems that occur in students is to provide help through guidance and counselling services that are carried out or provided by school counselor involving peers in the counselling process through peer counsellors. Guidance and Counseling as a place for appropriate scientific fields to provide the understanding and overcome problems in students (Menesini \& Salmivalli, 2017). Bullying problems that occur in schools can be reduced by an understanding of bullying by peer counsellors. Group guidance services are activities that emphasize the process of conscious thinking, feelings, and behaviour of members to increase awareness of the growth and development of healthy individuals (Aswida, Marjohan, \& Gratitude, 2017). It is expected that increasing peer counsellor understanding influences the creation of comfort in interacting with fellow students to prevent students from bullying behaviour and reduce bullying for those who have committed bullying. 


\section{Method}

The research method using Quasi Experiment approach to the design of the NonEquivalent Control Group, Subject Research is subject of the study 10 peer counsellors as the control group and 10 peer counsellors as an experimental group identified as having a low and moderate understanding about bullying. Data were collected using a peer counselor understanding scale about bullying (53 valid items $=0.949$ ). As for the aspect of understanding measured can be seen in the following table.

Table 1.Peer Counselor understanding about Bullying

\begin{tabular}{|c|c|c|}
\hline variables & sub Variables & Indicator \\
\hline \multirow{11}{*}{$\begin{array}{l}\text { An understanding of } \\
\text { Bullying }\end{array}$} & \multirow{4}{*}{ translating Bullying } & $\begin{array}{l}\text { The intention of the } \\
\text { perpetrators of bullying }\end{array}$ \\
\hline & & $\begin{array}{l}\text { Action hurts the victim of } \\
\text { bullying }\end{array}$ \\
\hline & & $\begin{array}{l}\text { Done repeatedly in a given } \\
\text { period by bullies }\end{array}$ \\
\hline & & $\begin{array}{l}\text { The imbalance of power } \\
\text { between the perpetrator and } \\
\text { the victim of bullying }\end{array}$ \\
\hline & \multirow{4}{*}{$\begin{array}{l}\text { Interpret Form } \\
\text { Bullying }\end{array}$} & bullying physical \\
\hline & & bullying verbal \\
\hline & & bullying social \\
\hline & & cyber or electronic \\
\hline & \multirow{3}{*}{$\begin{array}{l}\text { Mengektrapolasi } \\
\text { Impact of Bullying }\end{array}$} & victims of bullying \\
\hline & & Bullies \\
\hline & & Students who witness bullyir \\
\hline
\end{tabular}

Data analysis with Wilcoxon Signed Ranks Test to see the difference in the average score peer counsellor understanding about bullying before and after the experimental group participated in group counselling services. The results of the experimental group pretest and posttest can be seen in the following table.

Table 2. Differences Score Peer Counselor Understanding About Bullying Group Experiments

\begin{tabular}{|l|r|}
\hline & \multicolumn{1}{|c|}{ pretest and posttest } \\
\hline$Z$ & $-2,805 b$ \\
\hline Asymp. Sig. (2-tailed) &, 005 \\
\hline
\end{tabular}

Analysis of differences in understanding peer counsellor about bullying at pretest and posttest control group using Wilcoxon Signed Ranks Test analysis. The experimental group 
that was given treatment programmed group guidance services obtained changes. The peer counselor's understanding of bullying, which was originally in the low category, increased to the medium category. Understanding of peer counsellors on bullying for pretest and posttest control group without joining the group counselling services can be seen the difference scores understanding peer counsellor about bullying in the following table.

Table 3. Difference Score Peer Counselor Understanding About Bullying Control Group

\begin{tabular}{|c|c|}
\hline & pretest and posttest \\
\hline $\mathrm{Z}$ & $-2,546 \mathrm{~b}$ \\
\hline Asymp. Sig. (2-tailed) & .011 \\
\hline
\end{tabular}

Based on Table 3, known Asymp. Sig. (2-tailed) worth 0,011 less than 0.05, then the calculations, there is no difference in understanding bullying peer counsellor to the control group before and after without given treatment group counselling services.

To be able to see the different understanding about bullying on a peer counsellor group experiment and control group analyzed using nonparametric Kolmogorov-Smirnov statistic 2 Independent Sample, at posttest. Differences score peer counsellor understanding about bullying can be seen in the following table:

Based on data Table 4 above, it can be seen that the understanding of peer counsellor about bullying in Asymp column. Sig. (2-tailed) for the two-sided test is 0,015 with another form $(0.015<0.05)$, then there are significant differences of understanding about bullying peer counsellor experimental group who follow guidance counsellor peer group with the control group without following the guidance of the group.

\section{Results and Discussion}

The results showed that there were differences in the experimental group were given group counselling services. Based on the data of pretest and posttest experimental group and a control group that has been done shows that asymp Sig. (2-tailed) $0.015<0.05$, this means that the difference in the experimental group and the control group.

Table 4. Difference Score Experiment Group and Control

\begin{tabular}{|c|l|r|}
\hline \multicolumn{2}{|c|}{ An understanding of bullying } & \multicolumn{1}{c|}{ Score } \\
\hline \multirow{2}{*}{$\begin{array}{c}\text { Most Extreme } \\
\text { Differences }\end{array}$} & Absolute &, 700 \\
\cline { 2 - 3 } & positive &, 000 \\
\cline { 2 - 3 } & negative &,- 700 \\
\hline Kolmogorov-Smirnov Z & 1,565 \\
\hline \multicolumn{2}{|l}{ Asymp. Sig. (2-tailed) } & .015 \\
\hline
\end{tabular}

With the given group counselling services to peer counsellor as an experimental group then changes the understanding of bullying on self peer counsellor, compared peer counsellor control group with no treatment given group counselling services. Very precise 
guidance services group implemented as a contribution to provide information and sharing skills prevent problems that arise (Syam, 2019).

Results of research conducted by Aydin (2009) about the effectiveness of group counselling services in choosing a field of study in secondary school revealed a change in behaviour on a given student group counselling services to those without a given group counselling services. Olusakin (2017) conducted a study using the services of group guidance in the use of computer technology in the experimental group and without the use of guidance services group in the control group the results of research conducted showed significant differences between the groups of experimentation and control to a better understanding of the untreated. The same thing also expressed about the importance of understanding about bullying that occurs at school according to (Rosmawati \& Lestari, 2018) one of the efforts made to prevented or bullying behaviour among students that with the implementation of a peer counsellor training activities. Peer counselors can create effective programs in collaboration with various stakeholders of the school in terms of increasing understanding of the dangers of bullying. These materials are integrated into the materials research group counselling services, after giving treatment to a peer counsellor to a change rate of the bullying behaviour of students of the high category into the category of being. This is an indication that the application of peer counsellors provide a real and positive influence on the behaviour of students in school bullying.

Sarmin (2017) stated that empowerment peer counsellor was effective and efficient in solving problems of the same age. The effectiveness of peer counsellors empowerment of prove that Maryatun research results about the implementation process of peer counsellors through PIK R / M. Results The study found that the group that has empowered the peer counsellors with good impact developments and positive behaviour changes from previous students tend to behave negatively.

\section{Conclusion}

The result obtained through this study, a low understanding of peer counsellors can be enhanced by providing counselling services group. Implementation of guidance services is a support group that is prevention and understanding of the attitudes and the improper behaviour of a peer counsellor. Through group counselling activities to increase understanding of peer counsellors so that existing problems can be reduced bullying, peer counsellor can also give more attention and closeness to students who become victims. Implementation of guidance services is a support group that is prevention and understanding of the attitudes and the improper behaviour of a peer counsellor.

Program implementation guidance services this group can become a regular activity for socialized into forms that exist in the school program. On the implementation of guidance, services are expected that each member of the group working together, have a caring and responsible in dealing with problems of bullying. Therefore, it needs the cooperation and active participation of principals, school counsellors, and peer counsellor collectively engaged to address the problem of bullying in particular, to provide a good impact to the students that there is school environment. 


\section{References}

Arofah, T. N., \& Suroso. (2015). Pola Asuh Otoriter, Konformitas dan Perilaku School Bullying. Persona, Jurnal Psikologi Indonesia, 4(9), 153-161. https://doi.org/10.1017/CBO9781107415324.004

Aydin, D. (2009). Effectiveness of a group guidance program on realistic study field choice among first year high school student. Journal of Theory and Practice in Education, 5(1), 6784.

Marlina, M., Hendrawati, T., \& Kusumastuti, G. (2019). Teachers' Attitude Towards Learning Achievement Of Students With Learning Disabilities In Inclusive Schools. Journal of ICSAR, 3(1), 32-36.

Marlina, M., \& Kusumastuti, G. (2019). Social participation of students with special educational needs in inclusive elementary schools/specialiuju ugdymosi poreikiu turinčiu mokinių socialinis dalyvavimas inkliuzinëje pradinio ugdymo mokykloje. Specialusis ugdymas/special Education, 1(39), 109-132.

Nickerson, A. B. (2019). Preventing and Intervening with Bullying in Schools : A Framework for Evidence-Based Practice. School Mental Health, 11(1), 15-28. https://doi.org/10.1007/s12310-017-9221-8

Olusakin, A. M. (2017). The Impact of Group Guidance on Graduate Counseling Students' Preference for the Use of Computer-based Technology. Journal of Social Sciences, 17(3), 211-218. https://doi.org/10.1080/09718923.2008.11892653

Prahardika, A. N. (2014). Upaya Meningkatkan Pemahaman Bahaya Bullying Melalui Bimbingan Klasikal pada Siswa. Psikopedagogi, 3(1), 51-57.

Rosmawati, S., \& Lestari, M. (2018). Peer Counselor Training untuk Mencegah perilaku Bullying. Indonesia Journal of Learning Education and Counseling, 1(1), 62-69.

Saman, A., Thalib, S. B., \& Bakhtiar, M. I. (2012). Konselor sebaya di sekolah: Upaya penanganan masalah pada Siswa SMK Telkom Makassar (pp. 507-511).

Sandri, R. (2015). Perilaku Bullying pada Remaja Panti Asuhan Ditinjau dari Kelekatan dengan Teman Sebaya dan Harga Diri. Jurnal Psikologi Tabularasa, 10(1), 43-57

Santrock, J. . (2010). Child Development: an introduction. McGraw-Hill. https://doi.org/10.1017/CBO9781107415324.004

Sarmin. (2017). Konselor Sebaya: Pemberdayaan teman sebaya dalam sekolah guna menanggulangi pengaruh negatif lingkungan. Brilliant: Jurnal Riset Dan Konseptual, 2(1), 102-112.

Swearer, S. M., \& Hyme, S. (2015). Understanding the Psychology of Bullying Moving Toward a Social-Ecological Diathesis-Stress Model. American Psychologist, 70(4), 344353. https://doi.org/10.1037/a0038929

Syam, H. (2019). Group Guidance Model with Cinema Counseling Technique as a Prevention of Lesbianism for Students. In Education and Humanities Research (Vol. 178, pp. 197-201).

Trisnani, R. P., \& Wardhani, S. Y. (2016). Perilaku Bullying di Sekolah. G-COUNS Jurnal Bimbingan Dan Konseling, 1(1), 82-91.

Wardhana, K. (2015). Buku Panduan Melawan Bullying. Retrieved from https://pelindunganak.org/article-pdf/manual-book-sudah-dong.pdf 